\title{
LEAD EXPOSURE AT A SCHOOL FOR CHILDREN WITH DEVELOPMENTAL DISABILITIES
}

Jason Bawden-Smith, Environmental Health Officer Jeremy McAnulty, Director

Southern Sydney Public Health Unit

Mark Bek, Acting Director

Central Sydney Public Health Unit

n July 1994 a paediatrician reported that an autistic child aged six years had been admitted to hospital for chelation therapy with a blood lead level of 3.86 micromoles per litre. The child had ingested some granular material containing 23 per cent lead. This material was found in the child's home, where it was possibly used to treat rising damp. In September 1994 the child was enrolled at a school for children and young people with developmental disabilities. In view of the child's history of pica and elevated blood lead level, the school environment was assessed for possible lead contamination. Because it was believed that many of the students at the school engaged in hand-to-mouth activities, they were also offered blood lead testing. This article reports the findings of the environmental and blood lead surveys, which were conducted in October 1994, and outlines interventions designed to reduce the lead burden.

\section{METHODS}

Environmental survey

The school principal identified areas in the school grounds where children played and attended classes. Environmental samples were collected from these areas, which included carpet, window wells, wooden floors, bare surface soil and peeling paint. The samples were tested for total lead using standard methods.

\begin{abstract}
Survey of children
Parents received letters advising them to have their children tested for lead levels, either through their general practitioners or at special clinics held at the school. Class teachers completed a form giving demographic information about the children and information on the frequency with which they put fingers or objects into their mouths. Data analysis focused on the relationship between blood lead levels and children's behaviour and demographic characteristics.
\end{abstract}

\section{RESULTS \\ Environmental study}

The school's administration building was a refurbished twostorey Victorian-style erected in the 1880s. The classrooms and other facilities were located in buildings constructed in the mid- to late $1970 \mathrm{~s}$. A month before this investigation began, contractors were employed to repaint the administration building. They sanded back lead-painted exterior timber and masonry surfaces.

Very high levels of lead contamination were found on interior and exterior surfaces of the administration building. The classrooms and associated facilities contained low levels of lead, except for carpets in classrooms 2 and 4 (Table 2).

\section{Survey of children}

At the time of the survey 76 children were attending the school in years 1-11. Their ages ranged from 3 to 18 years (median 9 years), and 57 ( 75 per cent) were male. Teachers reported that 26 ( 34 per cent) children frequently, 8 ( 11 per cent) sometimes and 41 (54 per cent) rarely placed objects in

\section{TABLE 2}

ENVIRONMENTAL LEAD RESULTS FOR THE SCHOOL, OCTOBER 1994 - BEFORE AND AFTER ABATEMENT

\begin{tabular}{|c|c|c|c|c|}
\hline \multicolumn{2}{|c|}{ Sample location and description (units) } & $\begin{array}{r}\text { Before } \\
\text { abatement }\end{array}$ & $\begin{array}{r}\text { After } \\
\text { abatement }\end{array}$ & $\begin{array}{r}\text { US EPA } \\
\text { guidelines }\end{array}$ \\
\hline \multicolumn{5}{|c|}{ Administration building } \\
\hline \multirow[t]{3}{*}{ Library } & vacuum cleaner dust (mg/kg) & 49,423 & carpet removed & $500-1,000$ \\
\hline & dust wipe floor $\left(\mu \mathrm{g} / \mathrm{m}^{2}\right)$ & $\begin{array}{r}9,389 \\
16,51\end{array}$ & $2,725^{\circ}$ & $\begin{array}{l}1,076 \\
8,608\end{array}$ \\
\hline & paint interior wall $(\% \text { w/w) })^{b}$ & $\begin{array}{r}16,451 \\
0.22\end{array}$ & $\begin{array}{r}9,941 \\
\text { N/A }\end{array}$ & $\begin{array}{r}8,608 \\
0.5\end{array}$ \\
\hline \multirow[t]{2}{*}{ Staffroom } & dust wipe floor $\left(\mu \mathrm{g} / \mathrm{m}^{2}\right)$ & 8,050 & $2,619^{a}$ & 1,076 \\
\hline & dust wipe window well $\left(\mu \mathrm{g} / \mathrm{m}^{2}\right)$ & 6,324 & 1,490 & 8,608 \\
\hline \multirow[t]{2}{*}{ Office dust } & wipe floor $\left(\mu \mathrm{g} / \mathrm{m}^{2}\right)$ & 2,144 & $1,219^{a}$ & 1,076 \\
\hline & dust wipe window well $\left(\mu \mathrm{g} / \mathrm{m}^{2}\right)$ & 3,818 & 1,611 & 8,608 \\
\hline \multirow[t]{2}{*}{ Classroom } & dust wipe floor $\left(\mu \mathrm{g} / \mathrm{m}^{2}\right)$ & 2,736 & $1,756^{\mathrm{a}}$ & 1,076 \\
\hline & dust wipe window well ( $\mu \mathrm{g} / \mathrm{m}^{2}$ ) & 3,667 & 2,373 & 8,608 \\
\hline Paint & exterior wall ( $\%$ w/w) & 10.53 & removed/covered & 0.5 \\
\hline Soil & perimeter of building $(\mathrm{mg} / \mathrm{kg})$ & $\begin{array}{l}30.60 \\
4,649\end{array}$ & $\begin{array}{r}\text { removed/covered } \\
371\end{array}$ & $\begin{array}{r}0.5 \\
400\end{array}$ \\
\hline \multicolumn{5}{|c|}{ Classrooms and common areas } \\
\hline \multirow[t]{2}{*}{ Classroom 2} & vacuum dust (mg/kg) & 1,033 & 521 & $500-1,000$ \\
\hline & paint hallway wall $(\%$ w/w) & 5.45 & removed/covered & 0.5 \\
\hline Classroom 4 & vacuum dust (mg/kg) & 1,156 & 460 & $500-1,000$ \\
\hline Other & vacuum dust (mg/kg) & $184-563$ & $248-417$ & $500-1,000$ \\
\hline classrooms & paint interior wall ( $\%$ w/w) & 0.06 & N/A & 0.5 \\
\hline Soil & $(\mathrm{mg} / \mathrm{kg})$ & $77^{c}$ & N/A & 400 \\
\hline Paint & handrails $(\% \mathrm{w} / \mathrm{w})$ & 0.45 & N/A & 0.5 \\
\hline Water & first flush from bubbler $(\mu \mathrm{g} / \mathrm{l})$ & 5 & N/A & 10 \\
\hline
\end{tabular}

new carpet on top

percentage weight for weight

arithmetic mean of 6 soil samples

N/A Not applicable since before abatement results are below standards 
their mouths, and that 27 ( 36 per cent) frequently, 12 (16 per cent) sometimes and 37 (49 per cent) rarely placed their fingers in their mouths.

Forty-two ( 55 per cent) of the children had venipuncture for blood lead level determination. The median blood lead was $0.22 \mu \mathrm{mol} / \mathrm{l}$ (range 0.10-2.57 $\mu \mathrm{mol} / \mathrm{l}$ ), and five children (12 per cent) had elevated lead levels $(>0.48 \mu \mathrm{mol} / \mathrm{l})$. There were no significant differences between children with elevated lead levels and others by age, sex or grade. Children reported by their teachers to place objects or their fingers in their mouths frequently were significantly more likely to have lead levels above $0.48 \mu \mathrm{mol} / 1$ than children who rarely placed objects or fingers in their mouths (Table 3 ).

\section{INTERVENTION}

To reduce lead exposure school staff restricted student access to potentially contaminated areas. Temporary fences were erected around the contaminated soil, carpets were replaced, and floors, windows, cupboards and other surfaces and objects (including books in the library) in and around the administration building were thoroughly cleaned. Soil around the perimeter of the administration building to a thickness of $10 \mathrm{~cm}$ was removed and the area was paved. All deteriorating paint was removed or encapsulated. Carpet in the classrooms was professionally cleaned. Cleaners were asked to wipe dust from painted wooden window wells and sills as a routine.

Repeat sampling after the abatement program showed soil lead contamination had been substantially reduced (Table 2).

The home environments of children with blood lead levels $>0.72 \mu \mathrm{mol} / \mathrm{l}$ were also investigated for lead contamination, and their parents were advised on ways to reduce their children's lead exposure and to minimise absorption.

\section{DISCUSSION}

This investigation showed there was significant lead contamination in the school environment. Our findings indicate that children with developmental disabilities may be at greater risk of lead exposure due to their behavioural characteristics such as pica and frequent hand-to-mouth activity.

The remedial work undertaken at the school reduced environmental lead contamination, minimising the risk for students. While dust lead levels on the floor in the administration building remained high despite intensive cleaning, they were covered with new carpet to prevent access. This finding demonstrated the difficulty in removing lead dust from surfaces that are not smooth and reinforces the importance of minimising the dispersal of dust when removing lead-based paints. Lead dust levels remained high in window wells in the administration building due to the dust created by friction when the sash windows previously painted with a lead-based paint were opened and closed. Higher carpet dust levels in classrooms located closest to the administration building may be attributed to students and staff "tracking" contaminated soil and dust on their shoes from the administration building.

Lead is a potent neurotoxin that adversely affects many systems in the body, especially the central nervous system, the renal system and blood-forming tissues ${ }^{1}$. Recent studies have shown adverse neuro-psychological effects associated with elevated blood lead levels in children ${ }^{2}$,

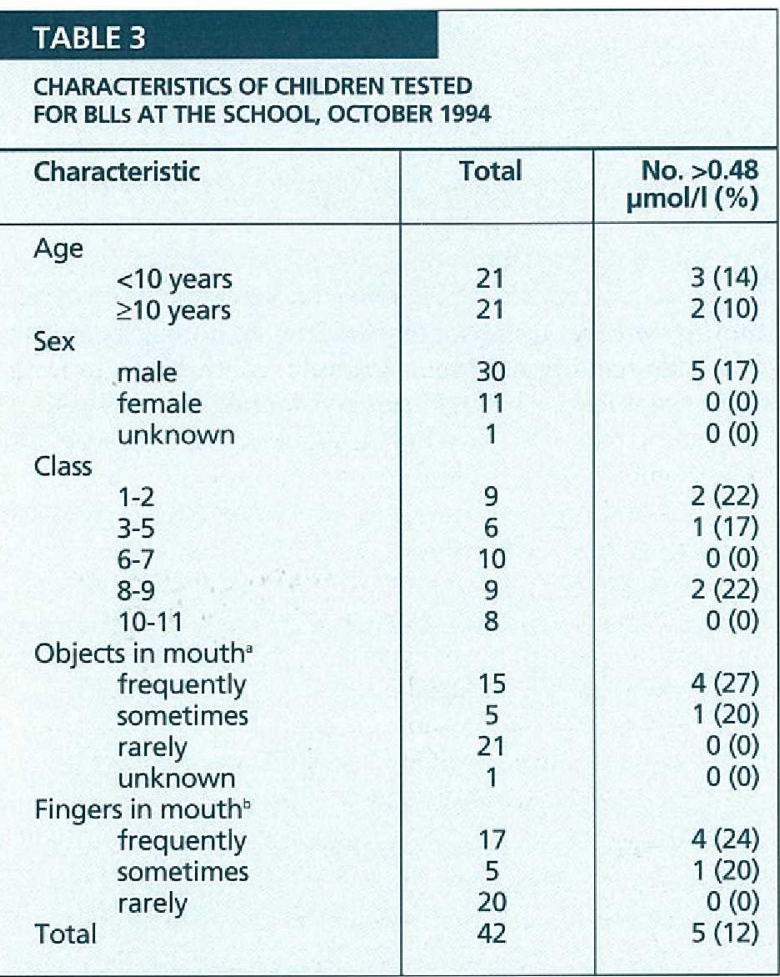

a chisquare for trend $5.8, p<0.02$

b chisquare for trend $4.8, p<0.03$

including reduced intelligence quotient $t^{3}$, attention deficits ${ }^{4}$, aggression and destructive behaviours $\mathrm{s}^{5}$. Damage to the central nervous system may be permanent, resulting in school failure and anti-social behaviour, and ultimately impairing productivity ${ }^{*}$.

Levels of environmental lead contamination found in areas around the administration block of the school were well above North American intervention guidelines ${ }^{6}(<0.5 \%$ in paint, $400 \mathrm{mg} / \mathrm{kg}$ in accessible bare soil in play areas, lead dust loading for floor $<1076 \mu \mathrm{g} / \mathrm{m}^{2}$, window sills, $5380 \mu \mathrm{g} / \mathrm{m}^{2}$ and window wells $<8608 \mu \mathrm{g} / \mathrm{m}^{2}$ ).

Twelve per cent of the 42 children tested had blood lead levels above the National Health and Medical Research Council goal $(<0.48 \mu \mathrm{mol} / /)$. This was no higher than levels found in preschool children in Central and Southern Sydney ${ }^{7}$ but may be higher than expected for primary school children. Children in this study who frequently placed their fingers and other objects in their mouths were more likely to have high blood lead levels.

A major limitation of the survey was the disappointing response to the offer of blood lead testing, with only 55 per cent of students being tested. The extent to which this group represented the school's entire enrolment is unknown. Another limitation was the reliance on teacher reports of hand-to-mouth activity after the blood screening of students.

This investigation was initiated in response to a need to protect a child with a history of an elevated blood lead level. 
TABLE 4

NSW PUBLIC HEALTH UNITS

\begin{tabular}{|c|c|c|c|c|}
\hline Code & Unit & Address & Phone & Facsimile \\
\hline CC PHU & Central Coast Public Health Unit & $\begin{array}{l}\text { PO Box } 361 \\
\text { GOSFORD } 2250\end{array}$ & 043204545 & 043204550 \\
\hline CS PHU & Central Sydney Public Health Unit & $\begin{array}{l}\text { PO Box } 374 \\
\text { CAMPERDOWN } 2050\end{array}$ & 025506810 & 025651690 \\
\hline CW PHU & Central West Public Health Unit & $\begin{array}{l}\text { PO Box } 143 \\
\text { BATHURST } 2795\end{array}$ & 063328505 & 063328577 \\
\hline ES PHU & Eastern Sydney Public Health Unit & $\begin{array}{l}\text { Locked Bag } 88 \\
\text { RANDWICK } 2031\end{array}$ & 023138322 & 023136291 \\
\hline HUN PHU & Hunter Public Health Unit & $\begin{array}{l}\text { PO Box } 11 \mathrm{~A} \\
\text { NEWCASTLE } 2300\end{array}$ & 049291292 & 049294037 \\
\hline ILL PHU & Illawarra Public Health Unit & $\begin{array}{l}\text { PO Box } 66 \\
\text { KEIRAVILLE } 2500\end{array}$ & 042264677 & 042264917 \\
\hline NCPHU & North Coast Public Health Unit & $\begin{array}{l}\text { PO Box } 498 \\
\text { LISMORE } 2480\end{array}$ & 066217231 & 066222151 \\
\hline ND PHU & Northern Districts Public Health Unit & $\begin{array}{l}\text { PO BOX } 597 \\
\text { TAMWORTH } 2340\end{array}$ & 067662288 & 067663003 \\
\hline NS PHU & Northern Sydney Public Health Unit & $\begin{array}{l}\text { Hornsby Ku-ring-gai Hospital } \\
\text { Palmerston Road } \\
\text { HORNSBY } 2077\end{array}$ & 024779400 & 024821650 \\
\hline SE PHU & South Eastern Public Health Unit & $\begin{array}{l}\text { Locked Mail Bag } 11 \\
\text { GOULBURN } 2580\end{array}$ & 048273428 & 048273438 \\
\hline SS PHU & Southern Sydney Public Health Unit & $\begin{array}{l}\text { PO Box } 482 \\
\text { KOGARAH } 2217\end{array}$ & 023503377 & 023503474 \\
\hline SW CPH & South West Centre for Public Health & $\begin{array}{l}\text { PO Box } 503 \\
\text { ALBURY } 2640\end{array}$ & 060581700 & 060581701 \\
\hline SWS PHU & South Western Sydney Public Health Unit & $\begin{array}{l}\text { Locked Bag } 17 \\
\text { LIVERPOOL } 2170\end{array}$ & 028285944 & 028285955 \\
\hline WN PHU & Western NSW Public Health Unit & $\begin{array}{l}\text { PO Box M61 } \\
\text { EAST DUBBO } 2830\end{array}$ & 068812235 & 068847223 \\
\hline WS PHU & Western Sector Public Health Unit & $\begin{array}{l}13 \text { New Street } \\
\text { NTH PARRAMATTA } 2151\end{array}$ & 028403603 & 028403608 \\
\hline
\end{tabular}

(Compiled by the South West Centre for Public Health on behalf of the Public Health Network)

\section{Lead exposure at a school}

\section{Continued from page 125}

As a consequence an environmental assessment of the child's new school was carried out. Subsequently, other students at the school were offered blood lead testing and public health action was taken to reduce lead exposure within the school grounds. The study highlighted the benefits of notification of elevated blood lead levels to public health authorities, following NHMRC recommendations. Public health action can then be taken to reduce exposures. The study also drew attention to the value of targeting children with developmental disabilities for lead screening, especially those in potentially contaminated environments and those who frequently engage in hand-to-mouth activity.
1. National Research Council. Measuring lead exposure in infants, children and other sensitive populations. Committee on Measuring Lead in Critical Populations. Board of Environmental Studies and Toxicology. Commission on Life Sciences. Washington DC: National Academy of Press, 1993

2. Needleman H, Bellinger D. The health effects of low pressure to lead. Ann Rev Pub Hith 1991; 12:111-140.

3. McMichael A.J, Baghurst PA, Wigg NR et al. Port Pirie cohort study: Environment exposure to lead and children's intelligence at the age of seven years. N Engl J Med 1992; 327:1279-84.

4. Needleman H, Schell A, Bellinger D, Leviton A, Allred EN. The longterm effects of exposure to low doses of lead in childhood. An 11-year follow-up report. $N$ Engl J Med 1990, 322:82-88.

5. Sciarillo WG, Alexander G, Farrell KP. Lead exposure and child behaviour. Am J Public Health 1992; 82:1356-1360.

6. National Centre for Lead Safe Housing. Guidelines for the Evaluation of Lead-based Paint Hazards in Housing. February 1995.

7. Mira M, Bawden-Smith J, Causer J, Alperstein A, Karr M, Snitch P,

Waller G, Fett J. Blood lead concentrations of urban Australian children. Submitted to Am J Paed. 